Edubiotik: Jurnal Pendidikan, Biologi dan Terapan
ISSN 2528-679X (print), ISSN 2597-9833 (online)
Volume 4, Nomor 02, Tahun 2019, Hal. 101-109
Available online at:
http://ejurnal.budiutomomalang.ac.id/index.php/edubiotik

\title{
Pengaruh jenis pelarut pada ekstrak daun kelor (Moringa oleifera) terhadap mortalitas larva Aedes aegypti
}

\author{
Restiani Sih Harsanti ${ }^{1}$, Ratna Mustika Yasi ${ }^{2}$ \\ ${ }^{1}$ Program Studi Teknologi Hasil Pertanian, Universitas PGRI Banyuwangi, Banyuwangi, Indonesia \\ 2Program Studi Teknik Elektro, Universitas PGRI Banyuwangi, Banyuwangi, Indonesia \\ E-mail: restiani.sh@gmail.com*,nanacan12@gmail.com
}

\begin{tabular}{|c|c|}
\hline Informasi Artikel & ABSTRACT \\
\hline $\begin{array}{l}\text { Submit: } \\
01-08-2019 \\
\text { Diterima: } \\
21-08-2019 \\
\text { Dipublikasikan: } \\
01-09-2019\end{array}$ & $\begin{array}{l}\text { Innovation is needed using alternative ingredients as natural larvacide instead } \\
\text { of temefos. One of the plants that can be used for making natural larvacide is } \\
\text { Moringa (Moringa oleifera) which contains alkaloids and flavonoids. This study } \\
\text { aims to determine the effect of the type of solvent on Moringa (M. oleifera) } \\
\text { extract on the mortality of Aedes aegypti larvae and determine the most } \\
\text { effective solvent in extracting Moringa leaves as A. aegypti larvacide. This } \\
\text { study uses a completely randomized design with } 5 \text { replications. Moringa leaf } \\
\text { extract is obtained by maceration with aquades, ethanol, methanol, ethyl } \\
\text { acetate, and n-hexane. Moringa leaf extracts were tested for phytochemistry } \\
\text { and larvacidal power was tested for A. aegypti larvae. Mortality data were } \\
\text { analyzed by ANOVA and Tukey tests. The results showed that the type of } \\
\text { solvent in moringa leaf extract (M. oleifera) did not significantly influence the } \\
\text { mortality of A. aegypti larvae and the most effective type of solvent for } \\
\text { extraction of Moringa leaves were aquades and ethanol. Based on the } \\
\text { research findings it can be concluded that the type of solvent in moringa leaf } \\
\text { extract does not significantly influence the mortality of A. aegypti larvae. } \\
\text { However, the most effective types of solvents for extraction of Moringa leaves } \\
\text { are aquades and ethanol. } \\
\text { Key words: Aedes aegypti, Larvacide, Moringa, Solvent }\end{array}$ \\
\hline Penerbit & ABSTRAK \\
\hline $\begin{array}{l}\text { Program Studi } \\
\text { Pendidikan Biologi, } \\
\text { Fakultas Pendidikan } \\
\text { Ilmu Eksakta dan } \\
\text { Keolahragaan, IKIP } \\
\text { Budi Utomo, Malang, } \\
\text { Indonesia }\end{array}$ & $\begin{array}{l}\text { Dibutuhkan suatu inovasi menggunakan bahan alternatif sebagai larvasida } \\
\text { alami pengganti temefos. Salah satu tanaman yang bisa digunakan untuk } \\
\text { pembuatan larvasida alami adalah kelor (Moringa oleifera) yang memiliki } \\
\text { kandungan alkaloid dan flavonoid. Penelitian ini bertujuan untuk mengetahui } \\
\text { pengaruh jenis pelarut pada ekstrak kelor ( } M \text {. oleifera) terhadap mortalitas } \\
\text { larva Aedes aegypti dan menentukan pelarut paling efektif dalam } \\
\text { mengekstraksi daun kelor sebagai larvasida A. aegypti. Penelitian ini } \\
\text { menggunakan Rancangan Acak Lengkap (RAL) dengan } 5 \text { ulangan. Ekstrak } \\
\text { daun kelor diperoleh melalui maserasi dengan pelarut aquades, etanol, } \\
\text { methanol, etil asetat, dan n-heksan. Ekstrak daun kelor diuji fitokimia dan } \\
\text { akan diuji daya larvasida pada larva } A \text {. aegypti. Data mortalitas dianlisis } \\
\text { dengan uji ANOVA dan Tukey. Hasil penelitian menunjukkan jenis pelarut } \\
\text { pada ekstrak daun kelor }(M \text {. oleifera) tidak berpengaruh signifikan terhadap } \\
\text { mortalitas larva } A \text {. aegypti dan jenis pelarut yang paling efektif untuk ekstraksi } \\
\text { adalah aquades dan etanol. Berdasarkan temuan penelitian dapat } \\
\text { disimpulkan bahwa jenis pelarut pada ekstrak daun kelor tidak berpengaruh } \\
\text { secara signifikan terhadap mortalitas larva } A \text {. aegypti. Akan tetapi jenis } \\
\text { pelarut paling efektif untuk ekstraksi daun kelor adalah aquades dan etanol. } \\
\text { Kata kunci: Aedes aegypti, Kelor, Larvasida, Pelarut }\end{array}$ \\
\hline
\end{tabular}

This Edubiotik : Jurnal Pendidikan, Biologi dan Terapan is licensed under a CC BY-SA (Creative Commons Attribution-ShareAlike 4.0 International License) 


\section{PENDAHULUAN}

Aedes aegypti merupakan vektor dari penyakit serius seperti malaria, encephalitis, yellow fever, DBD, filariasis, dan arbovirus yang menyebabkan masalah cukup besar pada kesehatan masyarakat di negara-negara dengan iklim tropis, termasuk Indonesia (Ndione, Faye, Ndiaye, Dieye, \& Afoutou, 2007). Penyakit ini telah dikenal di Indonesia sebagai penyakit yang endemis, terutama bagi anak-anak. Berdasarkan data dari Direktorat Pencegahan dan Pengendalian Penyakit Tular Vektor dan Zoonotik, Kemenkes RI, pada tahun 2017, terhitung sejak Januari hingga Mei tercatat sebanyak 17.877 kasus, dengan 115 kematian. Angka kesakitan atau Incidence Rate (IR) di 34 provinsi di 2015 mencapai 50,75 per 100 ribu penduduk, dan IR di 2016 mencapai 78,85 per 100 ribu penduduk. Angka ini masih lebih tinggi dari target $I R$ nasional yaitu 49 per 100 ribu penduduk (Depkes, 2017).

Berbagai upaya dilakukan untuk menekan peningkatan penderita DBD di Indonesia. Tindakan pencegahan dari timbulnya penyakit ini salah satunya dengan penggunaan larvasida. Larvasida yang sering ditemui di lapangan adalah abate (bahan aktif temefos 1\%). Pada tahun 1980, temefos 1\% (abate) ditetapkan sebagai bagian dari program pemberantasan massal Aedes aegypti di Indonesia (Ismatullah, Kurniawan, Wintoko, \& Setianingrum, 2014). Pemakaian temefos yang berulang mengakibatkan munculnya resistensi dari berbagai macam spesies nyamuk. Resistensi larva Aedes aegypti terhadap temefos sudah ditemukan di 15 lokasi di kota Havana, Cuba (Bisset et al., 2011).

Berdasarkan hal tersebut, dibutuhkan suatu inovasi untuk menggunakan bahan alternatif yang bisa digunakan sebagai larvasida dan juga ramah lingkungan. Insektisida nabati berbahan dasar dari tumbuhan yang mengandung senyawa bioaktif yang toksik terhadap serangga (Moehammadi, 2005). Bahan aktif tersebut bisa didapatkan dari tumbuhan yang mengandung berbagai fitokimia bioaktif berpotensi sebagai larvasida (Bhattacharya \& Chandra, 2015). Larvasida alami merupakan contoh pengendalian hama alternatif yang layak dikembangkan karena senyawa larvasida dari tumbuhan mudah terurai di lingkungan, tidak meninggalkan residu di udara, air, dan tanah serta relatif lebih aman (Astuti, Riyadi, \& Ahmadi, 2017).

Salah satu tanaman yang dapat digunakan untuk membuat larvasida alami adalah kelor (Moringa oleifera). Seluruh bagian dari tanaman kelor dapat dimanfaatkan sebagai bahan pangan maupun obat-obatan. Bagian tanaman kelor yang sering digunakan sebagai obat adalah biji, daun, dan kulit kayu (Putra, Dharmayudha, \& Sudimartini, 2016). Daun tanaman kelor mengandung fenol, hidrokuinon, flavonoid, steroid, triterpenoid, tanin, alkaloid, dan saponin. Senyawa metabolit sekunder alkaloid dan flavonoid mampu memberikan efek larvasida terhadap larva nyamuk (Kiswandono, 2011).

Pengambilan senyawa aktif dalam tumbuhan dapat dilakukan dengan ekstraksi pelarut. Beberapa faktor yang mempengaruhi dalam pemilihan jenis pelarut antara lain selektivitas, kemampuan untuk mengekstrak, toksisitas, kemudahan untuk diuapkan, dan harga pelarut (Harbone, 1987). Larutan pengekstraksi yang digunakan disesuaikan dengan kepolaran senyawa yang diinginkan. Menurut prinsip like dissolves like, suatu pelarut akan cenderung melarutkan senyawa yang mempunyai 
tingkat kepolaran yang sama. Pelarut polar akan melarutkan senyawa polar dan sebaliknya (Harbone, 1987).

Faktor penting yang harus dipenuhi dalam melakukan ekstraksi adalah pemilihan pelarut. Persentase ekstraksi dipengaruhi oleh tipe pelarut dengan berbagai kepolaran dan $\mathrm{pH}$, serta komposisi kimia dan sifat fisik dari sampel (Xu BJ and Chang SK, 2007). Pemilihan jenis pelarut didasarkan pada senyawa aktif yang terkandung dalam ekstrak bahan. Senyawa aktif yang bersifat polar akan larut pada pelarut polar, sedangkan senyawa yang bersifat non polar akan larut dalam pelarut non polar, sesuai dengan konsep like dissolve like (Arifianti, Oktarina, \& Kusumawati, 2014).

Flavonoid merupakan senyawa golongan polifenol yang terdistribusi luas pada tumbuhan dalam bentuk glikosida yang berikatan dengan suatu gula. Oleh karena itu, flavonoid merupakan senyawa yang bersifat polar. Pelarut alkohol atau campurannya dengan air merupakan pelarut ideal yang sering digunakan untuk mengekstraksi hampir semua senyawa dengan berat molekul rendah seperti saponin dan flavonoid (Wijesekera, 1991). Pelarut polar yang biasa digunakan untuk ekstraksi flavonoid adalah metanol, aseton, etanol, air dan isopropanol. Etanol merupakan senyawa organik yang tersusun dari unsur-unsur karbon, hidrogen, dan oksigen. Gugus $\mathrm{OH}$ dalam etanol membantu melarutkan molekul polar dan ion-ion dan gugus alkilnya $\mathrm{CH} 3 \mathrm{CH}$ dapat mengikat bahan non-polar (Aziz, Ratih, \& Fresca, 2009). N-heksana merupakan jenis pelarut nonpolar sehingga $n$-heksana dapat melarutkan senyawa-senyawa bersifat nonpolar (Maulida \& Zulkarnaen, 2014). Etil asetat merupakan pelarut semi polar dan dapat melarutkan senyawa semi polar pada dinding sel (Harbone, 1987). Metanol merupakan pelarut polar yang dapat melarutkan senyawa-senyawa yang bersifat polar seperti golongan fenol (Kusumaningtyas, Widiati, \& Gholib, 2008).

Senyawa yang terkandung dalam kelor dan berperan sebagai larvasida adalah alkaloid dan flavonoid. Alkaloid memiliki kemampuan sebagai racun perut dan menghambat kerja enzim kolinesterase pada larva, sedangkan flavonoid berperan sebagai racun pernafasan sehingga menyebabkan kematian larva. Hal tersebut menandakan bahwa senyawa metabolit sekunder alkaloid dan flavonoid yang mampu memberikan efek larvasida terhadap larva nyamuk. Pemilihan pelarut yang tepat pada metode ekstraksi akan mengoptimalkan ekstraksi senyawa fenolik yang terdapat pada daun kelor. Pelarut merupakan salah satu faktor yang mempengaruhi mutu ekstrak (Aradilla, 2009). Penelitian ekstrak daun kelor selama ini hanya terbatas pada konsentrasi larutan ekstrak kelor dengan menggunakan pelarut ethanol dan aquadest saja (Kiswandono, 2011; Yasi \& Harsanti, 2018). Berdasarkan informasi tersebut peneliti tertarik untuk mengetahui pelarut yang tepat digunakan untuk ekstraksi daun kelor yang dapat digunakan sebagai larvasida Aedes aegypti.

Berdasarkan uraian di atas, maka penelitian kali ini bertujuan untuk mengetahui pengaruh jenis pelarut pada ekstrak kelor terhadap mortalitas larva $A$. aegypti dan menentukan pelarut yang paling efektif dalam mengekstraksi daun kelor sebagai larvasida $A$. aegypti. 


\section{METODE PENELITIAN}

Penelitian ini merupakan penelitian eksperimental. Rancangan percobaan menggunakan Rancangan Acak Lengkap (RAL) yang terdiri dari 5 perlakuan pelarut, sebagai berikut. P1 = Pelarut Aquadest, P2 = Pelarut etanol, P3 = Pelarut methanol, P4 = Pelarut etil asetat, dan P5 = Pelarut n-heksana.

Masing-masing perlakuan diulang sebanyak 5 kali. Adapun desain rancangan RAL pada penelitian ini tersaji pada Tabel 1.

Tabel 1. Desain Rancangan RAL Pada Penelitian

\begin{tabular}{ccccc}
\hline Ulangan 1 & Ulangan 2 & Ulangan 3 & Ulangan $\mathbf{4}$ & Ulangan 5 \\
\hline P1 & P3 & P2 & P3 & P4 \\
P2 & P4 & P5 & P1 & P5 \\
P5 & P3 & P2 & P1 & P1 \\
P4 & P5 & P2 & P4 & P5 \\
P1 & P3 & P4 & P2 & P3 \\
\hline
\end{tabular}

Bahan-bahan yang digunakan dalam penelitian adalah daun kelor, larutan etanol $70 \%$, larutan methanol, larutan etil asetat, larutan $\mathrm{n}$ heksana, aquadest, larutan $\mathrm{Na}-\mathrm{CMC} 1 \%, \mathrm{NaOH} 10 \%$, pereaksi Mayer, larva Aedes aegypti instar III, fish food. Alat-alat yang digunakan adalah neraca analitik, pipet, gelas ukur $1000 \mathrm{cc}$, nampan plastik, toples plastik (sebagai kontainer), beaker glass, kain (sebagai pelindung agar nyamuk dewasa tidak terbang keluar), blender atau juicer, batang pengaduk kaca, papan plat tetes porselen, corong pemisah, ekstraktor (peralatan maserasi), evaporator, kertas saring, kertas label, pisau, labu takar $50 \mathrm{~mL}$, pipet volume, pipet tetes, sarung tangan, cawan porselen, dan stopwatch atau penghitung waktu.

Tahap persiapan percobaan dimulai dengan mengeringkan 10 gram daun kelor yang telah dibersihkan. Daun kelor kering kemudian dihaluskan menggunakan blender. Proses selanjutnya kemudian melakukan maserasi. Sebanyak 300 mg serbuk daun kelor dilarutkan dalam $1 \mathrm{~L}$ larutan sesuai dengan perlakuan jenis pelarut (aquadest, etanol, methanol, etil asetat, dan n-heksan) yang telah ditentukan. Masing-masing campuran serbuk daun kelor dengan pelarut sesuai dengan perlakuan didiamkan selama 24 jam. Setelah 24 jam, kemudian larutan tersebut disaring menggunakan kertas saring. Penyaringan dilakukan sebanyak 3 kali supaya semua zat yang terkandung dalam daun kelor tersebut terekstrak.

Ekstrak daun kelor pada 5 macam pelarut kemudian diuji kandungan alkaloid dan flavonoidnya. Pengujian fitokimia dilakukan secara kualitatif menggunakan pereaksi Mayer untuk menguji kandungan alkaloid dan $\mathrm{NaOH}$ untuk menguji kandungan flavonoid. Setelah dilakukan uji fitokimia, lalu dilanjutkan dengan uji larvasida ekstrak daun kelor dengan pelarut aquades, etanol, methanol, etil asetat, dan $\mathrm{n}$-heksan. Pengujian larvasida dengan cara mengamati jumlah larva $A$. aegypti yang mati saat diberikan ekstrak daun kelor. Pengujian larvasida ekstrak daun kelor dimulai dengan menyiapkan 25 wadah dan masing-masing wadah diisi 10 ekor larva, setelah itu diberi 10 tetes ekstrak daun kelor dengan pemakaian 5 variasi pelarut dan dihitung kematiannya dengan kurun waktu 1 × 24 jam. Pengamatan jumlah larva yang mati dilakukan setiap 2 jam sekali selama 24 jam. Cara perhitungan larva mati 
dilakukan secara manual. Data mortalitas (kematian) larva yang telah didapatkan kemudian dianalisis menggunakan ANOVA dan uji Tukey $5 \%$.

\section{HASIL PENELITIAN DAN PEMBAHASAN}

Hasil percobaan ditunjukkan dengan hasil uji ANOVA yang digunakan untuk mengetahui pengaruh jenis pelarut dalam ekstrak daun kelor terhadap mortalitas larva Aedes aegypti. Berdasarkan hasil uji ANOVA dapat diketahui bahwa perlakuan jenis pelarut dalam ekstrak daun kelor terhadap mortalitas larva Aedes aegypti tidak memberikan pengaruh nyata pada waktu pengamatan 2 sampai 24 jam. Adapun rangkuman hasil uji ANOVA tersaji pada Tabel 1.

Tabel 1. Hasil Uji ANOVA Pengaruh Jenis Pelarut dalam Ekstrak Daun Kelor terhadap Mortalitas Larva Aedes aegypti

\begin{tabular}{ccc}
\hline Waktu pengamatan (jam) & Signifikasi perlakuan & Galat \\
\hline 2 & $0 \mathrm{~ns}$ & 0 \\
4 & $0,06 \mathrm{~ns}$ & 0,24 \\
6 & $0,16 \mathrm{~ns}$ & 0,28 \\
8 & $0,1 \mathrm{~ns}$ & 0,68 \\
19 & $0,64 \mathrm{~ns}$ & 1,7 \\
12 & $0,26 \mathrm{~ns}$ & 2,36 \\
14 & $1,24 \mathrm{~ns}$ & 4,22 \\
16 & $1,06 \mathrm{~ns}$ & 4,47 \\
18 & $0,86 \mathrm{~ns}$ & 5,14 \\
20 & $1,24 \mathrm{~ns}$ & 6,12 \\
24 & $0,74 \mathrm{~ns}$ & 6,22 \\
\hline
\end{tabular}

Keterangan : ns $=$ tidak berbeda nyata

Setelah dilakukan ANOVA, kemudian dilanjutkan dengan uji lanjut Tukey 5\%. Hasil uji Tukey 5\% menyatakan bahwa pada waktu pengamatan 2, 6, 14 jam pada semua ekstrak daun kelor dengan jenis pelarut yang berbeda menunjukkan tidak ada perbedaan yang nyata dalam mematikan larva Aedes aegypti. Secara umum, dapat diketahui bahwa perlakuan ekstrak daun kelor dengan pelarut etanol memiliki mortalitas larva tertinggi pada waktu pengamatan 4, 20, 22, dan 24 jam. Sedangkan ekstrak daun kelor dengan pelarut aquades memiliki mortalitas larva tertinggi pada waktu pengamatan $8,10,12,16$, dan 18 jam. Berdasarkan data tersebut dapat diketahui bahwa pelarut aquades dan etanol merupakan pelarut yang efektif yang dapat digunakan untuk mengekstraksi daun kelor sebagai bahan larvasida Aedes aegypti. Rangkuman hasil uji lanjut Tukey 5\% dapat dilihat pada Tabel 2 dan Tabel 3.

Tabel 2. Rangkuman hasil uji lanjut Tukey $5 \%$ Waktu Pengamatan 12 Jam

\begin{tabular}{|c|c|c|c|c|c|c|c|c|c|c|c|c|}
\hline & \multicolumn{12}{|c|}{ Waktu (jam) } \\
\hline & \multicolumn{2}{|c|}{2} & \multicolumn{2}{|c|}{4} & \multicolumn{2}{|c|}{6} & \multicolumn{2}{|c|}{8} & \multicolumn{2}{|c|}{10} & \multicolumn{2}{|c|}{12} \\
\hline $\begin{array}{l}\text { Pelarut } \\
\text { Etanol }\end{array}$ & 0 & $a$ & 1 & $a$ & 1 & $\mathrm{a}$ & 1 & $a b$ & 2 & $a b$ & 2,2 & $a b$ \\
\hline Aquades & 0 & a & 0,4 & $a b$ & 0,8 & a & 1,6 & $\mathrm{a}$ & 2,6 & $\mathrm{a}$ & 3,4 & a \\
\hline metanol & 0 & a & 0 & b & 0,6 & a & 1,4 & $a b$ & 1,6 & $a b$ & 2 & $a b$ \\
\hline n-heksana & 0 & a & 0 & b & 0 & a & 0 & b & 0 & $\mathrm{~b}$ & 0 & $b$ \\
\hline Etil asetat & 0 & a & 0 & b & 0 & a & 0 & b & 0 & $\mathrm{~b}$ & 0 & $b$ \\
\hline
\end{tabular}

Keterangan : huruf yang sama menunjukkan tidak berbeda nyata menurut uji Tukey $5 \%$ 
Tabel 3. Rangkuman hasil uji lanjut Tukey 5\% Waktu Pengamatan 12 Jam Berikutnya

\begin{tabular}{|c|c|c|c|c|c|c|c|c|c|c|c|c|}
\hline \multirow{2}{*}{ Pelarut } & \multicolumn{12}{|c|}{ Waktu } \\
\hline & \multicolumn{2}{|c|}{14} & \multicolumn{2}{|c|}{16} & \multicolumn{2}{|c|}{18} & \multicolumn{2}{|c|}{20} & \multicolumn{2}{|c|}{22} & \multicolumn{2}{|c|}{24} \\
\hline Etanol & 3,8 & $\mathrm{a}$ & 3,8 & $a b$ & 4 & $a b$ & 5 & a & 5,8 & a & 5,8 & a \\
\hline Aquades & 3,8 & $\mathrm{a}$ & 4,4 & a & 4,6 & a & 4,8 & $a b$ & 4,8 & $a b$ & 5,2 & $a b$ \\
\hline metanol & 3,2 & $a$ & 3,2 & $a b$ & 3,6 & $a b$ & 3,8 & $a b$ & 3,8 & $a b$ & 4 & $a b$ \\
\hline n-heksana & 0 & a & 0 & $b$ & 0,2 & b & 0,4 & $a b$ & 0,8 & b & 1 & $a b$ \\
\hline Etil asetat & 0 & $\mathrm{a}$ & 0 & $b$ & 0 & $b$ & 0,2 & $b$ & 0,6 & $b$ & 0,8 & $b$ \\
\hline
\end{tabular}

Keterangan : huruf yang sama menunjukkan tidak berbeda nyata menurut uji Tukey $5 \%$

Ekstrak daun kelor yang telah dilarutkan pada lima jenis pelarut yakni aquades, etanol, methanol, etil asetat, dan n-heksana kemudian dilakukan uji fitokimia untuk mengetahui kandungan senyawa aktif alkaloid dan flavonoid dalam ekstrak daun kelor tersebut. Hasil uji fitokimia menunjukkan bahwa ekstrak kelor yang menggunakan pelarut aquades mengandung flavonoid dan alkaloid. Daun kelor yang diekstrak dengan menggunakan pelarut etanol, methanol dan etil asetat menunjukkan terdapat kandungan alkaloid tetapi tidak mengandung flavonoid, sedangkan pada perlakuan pelarut $\mathrm{n}$-heksan tidak mengandung baik alkaloid dan flavonoid. Hasil ekstrak ini kemudian digunakan untuk uji larvasida pada larva Aedes aegypti. Hasil uji fitokimia ekstrak daun kelor pada lima pelarut ditunjukkan pada Tabel 4.

Tabel 4. Hasil Uji Fitokimia Ekstrak Daun Kelor pada Lima Pelarut yang Berbeda

\begin{tabular}{ccc}
\hline Pelarut & Flavonoid & Alkaloid \\
\hline Aquadest & + & + \\
Etanol & - & + \\
Metanol & - & + \\
Etil asetat & - & + \\
n-Heksan & - & - \\
\hline
\end{tabular}

Penelitian ini menggunakan daun tanaman kelor sebagai bahan yang akan diektrak. Daun kelor dikeringkan terlebih dahulu, kemudian dihaluskan menggunakan blender. Tujuan dari kegiatan ini adalah untuk memperluas permukaan sampel pada tahap ekstraksi sehingga meningkatkan keefektifan interaksi antara pelarut pengekstrak dengan sampel yang akan diekstrak sehingga pengekstrak akan lebih mudah mengambil zat-zat yang terkandung dalam sampel (Kiswandono, 2011).

Pengoptimalan senyawa fenolik yang terdapat pada ekstrak kasar daun kelor dilakukan dengan variasi pelarut, yaitu menggunakan aquadest, etanol $70 \%$, metanol, etil asetat, dan n-heksan. Pelarut merupakan salah satu faktor kimia eksternal yang mempengaruhi mutu ekstrak (Aradilla, 2009). Hasil penelitian menunjukkan bahwa, perbedaan jenis pelarut dalam ekstrak daun kelor tidak memberikan pengaruh nyata terhadap mortalitas larva $A$. aegypti. Hal ini berarti semua pelarut dapat digunakan untuk mengekstrak daun kelor dan ekstrak daun kelor dari semua pelarut dapat digunakan untuk membunuh larva $A$. aegypti. Kendati demikian, pelarut aquadest dan etanol merupakan pelarut yang paling cocok digunakan untuk mengekstrak daun kelor sebagai bahan larvasida $A$. aegypti. Hal ini karena, ekstrak daun kelor dengan pelarut aquades dan ekstrak daun kelor dengan pelarut etanol terbukti memiliki tingkat kematian larva $A$. aegypti tertinggi 
dibandingkan dengan ekstrak daun kelor dengan pelarut metanol, etil asetat, dan nheksan.

Senyawa yang terkandung dalam kelor dan berperan sebagai larvasida adalah alkaloid dan flavonoid. Kandungan metabolit sekunder seperti alkaloid dan flavonoid dalam daun kelor dapat mempengaruhi sistem syaraf dan sistem pernafasan pada larva sehingga menyebabkan kematian (Arivoli, Raveen, \& Samuel, 2015). Alkaloid memiliki kemampuan sebagai racun perut dan menghambat kerja enzim kolinesterase pada larva, sedangkan flavonoid berperan sebagai racun pernafasan sehingga menyebabkan kematian larva. Hal tersebut menandakan bahwa senyawa metabolit sekunder alkaloid dan flavonoid yang mampu memberikan efek larvasida terhadap larva nyamuk. Pemilihan pelarut yang tepat pada metode ekstraksi akan mengoptimalkan ekstraksi senyawa fenolik yang terdapat pada daun kelor. Berdasarkan aktivitas, tampak bahwa ekstrak aquadest dan etanol daun kelor dapat dijadikan sebagai larvasida $A$. aegypti.

Hasil uji fitokimia menunjukkan bahwa daun kelor yang diekstrak dengan larutan aquadest mengandung flavonoid. Karakteristik senyawa flavonoid pada ekstrak daun kelor mempunyai kepolaran yang sama dengan aquadest. Flavonoid merupakan senyawa golongan polifenol yang terdistribusi luas pada tumbuhan dalam bentuk glikosida yang berikatan dengan suatu gula, karena itu flavonoid merupakan senyawa yang bersifat polar (Wijesekera, 1991). Menurut Flavonoid dibagi menjadi beberapa jenis dan tiap jenis flavonoid memiliki kepolaran berbeda tergantung dari jumlah serta posisi gugus hidroksil (Harbone, 1987). Pelarut alkohol atau campurannya dengan air merupakan pelarut ideal yang sering digunakan untuk mengekstraksi hampir semua senyawa dengan berat molekul rendah seperti saponin dan flavonoid (Wijesekera, 1991).

\section{SIMPULAN DAN SARAN}

Berdasarkan hasil penelitian, maka dapat disimpulkan bahwa perlakuan jenis pelarut dalam ekstrak daun kelor terhadap mortalitas larva Aedes aegypti tidak memberikan pengaruh nyata pada waktu pengamatan 2 sampai 24 jam (nilai sig < nilai galat). Jenis pelarut yang efektif untuk mengekstrak daun kelor sebagai bahan larvasida alami adalah aquades dan etanol. Hal tersebut dibuktikan dengan adanya kandungan alkaloid dan flavonoid hasil ekstrasi dengan pelarut aquades dan kandungan flavonoid pada pelarut etanol. Penelitian lebih lanjut mengenai pembuatan produk lotion badan dan obat nyamuk perlu dilakukan. Lotion dan obat nyamuk merupakan produk yang tidak terlepas kebutuhan masyarakat sehari-hari sehingga perlu adanya penelitian lanjutan untuk membuat poduk lotion menjadi produk lokal yang berbahan dasar alam.

\section{UCAPAN TERIMA KASIH}

Ucapkan terima kasih ditujukan kepada Direktorat Jenderal Riset dan Pengabdian Masyarakat Kemenristekdikti yang telah memberikan dana penelitian serta kepada semua pihak yang telah membantu dalam penyelesaian penelitian. 


\section{RUJUKAN}

Aradilla, A. S. (2009). Uji Efektivitas Larvasida. Core.Kmi.Open.Ac.Uk. Retrieved from http://core.kmi.open.ac.uk/download/pdf/11708628.pdf

Arifianti, L., Oktarina, R. D., \& Kusumawati, I. (2014). Pengaruh Jenis Pelarut Pengektraksi Terhadap Kadar Sinensetin Dalam Ekstrak Daun Orthosiphon stamineus Benth. E-Journal Planto Husada, 2(1), 3-6. Retrieved from http://journal.unair.ac.id/download-fullpapers-ph44bbad3916full.pdf

Arivoli, S., Raveen R., Tennyson, S., Sakthivadivel, M. (2015). Adult emergence inhibition activity of Cleistanthus collinus (Roxb.) (Euphorbiaceae) leaf extracts against Aedes aegypti (L.), Anopheles stephensi Liston and Culex quinquefasciatus Say (Diptera: Culicidae), 2(1): 24-28. Retrieved from http://www.dipterajournal.com/archives/2015/2/1/A/1-5-4

Astuti, E. P., Riyadi, A., \& Ahmadi, N. R. (2017). Efektivitas Minyak Jarak Pagar Sebagai Larvasida, Anti-Oviposisi Dan Ovisida Terhadap Larva Nyamuk. Buletin Penelitian Tanaman Rempah Dan Obat, 22(1), 44-53. https://doi.org/10.21082/bullittro.v22n1.2011

Aziz, T., Ratih, C. K. N., \& Fresca, A. (2009). Pengaruh Pelarut Heksana dan Etanol, Volume Pelarut, dan Waktu Ekstraksi Terhadap Hasil Ekstraksi Minyak Kopi. Jurnal Teknik Kimia, 16(1), 1-8. Retrieved from http://jtk.unsri.ac.id/index.php /jtk/article/view/61

Bhattacharya, K., \& Chandra, G. (2015). Biocontrol Efficacy of Operculina Turpethum (L.) (Convolvulaceae) Leaf Extractives against larval form of Malarial Mosquito Anopheles Stephensi (Liston 1901). Int J Pharm Bio Sci, 6(3), 460-468. Retrieved from https://www.semanticscholar.org/

Bisset, J. A., Rodríguez, M. M., Ricardo, Y., Ranson, H., Pérez, O., Moya, M., \& Vázquez, A. (2011). Temephos resistance and esterase activity in the mosquito Aedes aegypti in Havana, Cuba increased dramatically between 2006 and 2008. Medical and Veterinary Entomology, Vol. 25, pp. 233-239. https://doi.org/10.1111/j.1365-2915.2011.00959

Depkes. (2017). Kemenkes Optimalkan Psn Cegah DBD. Retrieved from http://www.depkes.go.id/pdf.php?id=17061500001

Harbone, J. B. (1987). Metode Fitokimia. Bandung: Penerbit ITB.

Ismatullah, A., Kurniawan, B., Wintoko, R., \& Setianingrum, E. (2014). Uji Efektivitas Larvasida Ekstrak Daun Binahong (Anredera Cordifolia (Ten.) Steenis) terhadap Larva Aedes Aegypti Instar III. Jurnal Majority, 3(5), 1-9. Retrieved from http://juke.kedokteran.unila.ac.id/index.php/majority/article/view/259

Kiswandono, A. A. (2011). Perbandingan Dua Ekstraksi Yang Berbeda Pada Daun Kelor (Moringa oleifera, lamk) Terhadap Rendemen Ekstrak Dan Senyawa Bioaktif Yang Dihasilkan. Sains Natural, 1(1), 45-51. Retrieved from http://www.ejournalunb.ac.id/index.php/JSN/article/down load/13/12

Kusumaningtyas, E., Widiati, R., \& Gholib, D. (2008). Uji Daya Hambat Ekstrak Daun Sirih (Piper betle) terhadap Candida albicans dan Trichophytan mentagioplites. Seminar Nasional Teknologi Peternakan dan Veteriner 2008. Retrieved from https://docplayer.info/

Maulida, D., \& Zulkarnaen, N. (2014). Ekstraksi Antioksidan ( Likopen ) Dari Buah Tomat Dengan Menggunakan Solven Campuran, N - Heksana, Aseton, Dan Etanol. Diponegoro University Institutional Repository. Retrieved from http://eprints.undip.ac.id/13444/

Moehammadi, N. (2005). Potensi biolarvasida ekstrak herba Ageratum conyzoides Linn. dan daun Saccopetalum horsifieldii Benn. terhadap larva nyamuk Aedes aegypti L. Journal of Biological Researches, 11(1), 1-4. https://doi.org/ 
10.23869/bphjbr.11.1.20051

Ndione, R. D., Faye, O., Ndiaye, M., Dieye, A., \& Afoutou, J. M. (2007). Toxic effects of neem products (Azadirachta indica A. Juss) on Aedes aegypti Linnaeus 1762 larvae. African Journal of Biotechnology, 6(24), 2846-2854. https://doi.org/10.5897/ajb2007.000-2454

Putra, I. W. D. P., Dharmayudha, A. A. G. O., \& Sudimartini, L. M. (2016). Identifikasi Senyawa Kimia Ekstrak Etanol Daun Kelor (Moringa oleifera L) di Bali. Indonesia Medicus Veterinus, 5(5), 464-473. Retrieved from https://ojs.unud. ac.id/index.php/imv/article/view/27257/17247

Wijesekera, R. O. B. (1991). The Medicinal Plant Industry. Washington DC: CRC Press.

Xu BJ and Chang SK. (2007). A comparative study on phenolic profiles and antioxidant activities of legumes as affected by extraction solvents. Journal of Food Science, Vol. 72. https://doi.org/10.1111/j.1750-3841.2006.00260

Yasi, R. M., \& Harsanti, R. S. (2018). The Larvacidal Activity of Moringa oloifera Extract Leaf to The Larva's Aedes aegypti Mortality. Journal of Agromedicine and Medical Sciences, 4(3), 159. https://doi.org/10.19184/ams.v4i3.8710 